\title{
The production of a recombinant tandem single chain fragment variable capable of binding prolamins triggering celiac disease
}

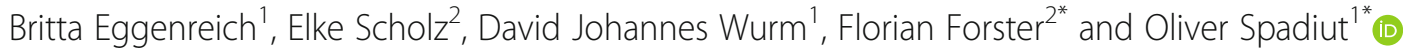

\begin{abstract}
Background: Celiac disease (CD) is one of the most common food-related chronic disorders. It is mediated by the dietary consumption of prolamins, which are storage proteins of different grains. So far, no therapy exists and patients are bound to maintain a lifelong diet to avoid symptoms and long-term complications. To support those patients we developed a tandem single chain Fragment variable (tscFv) acting as a neutralizing agent against prolamins. We recombinantly produced this molecule in E. coli, but mainly obtained misfolded product aggregates, so-called inclusion bodies, independent of the cultivation strategy we applied.

Results: In this study, we introduce this novel tscFv against CD and present our strategy of obtaining active product from inclusion bodies. The refolded tscFv shows binding capabilities towards all tested CD-triggering grains. Compared to a standard polyclonal anti-PT-gliadin-IgY, the tscFv displays a slightly reduced affinity towards digested gliadin, but an additional affinity towards prolamins of barley.
\end{abstract}

Conclusion: The high binding specificity of tscFv towards prolamin-containing grains makes this novel molecule a valuable candidate to support patients suffering from $C D$ in the future.

Keywords: Celiac disease, Single chain fragment variable, E. coli, Inclusion body, ELISA

\section{Background}

Celiac disease $(\mathrm{CD})$ is one of the most common food-related chronic disorders with a prevalence of 1$2 \%$ in Western nations $[1,2]$. It is triggered by the dietary consumption of storage proteins (prolamin, alcohol soluble fraction of gluten) of wheat, barley, rye and others [3, 4]. Up to date it is still not completely clear which factors lead to the manifestation of CD. Genetically, patients carry genes for the human leukocyte antigens HLA-DQ2 and HLA-DQ8, but also environmental factors, like early exposure to dietary gluten, infection and/or change in the bacterial flora of the intestine contribute to this disorder [1,3-5].

In patients with $C D$ the uptake of gluten leads to the secretion of autoantibodies and tissue transglutaminase (TG2), as well as proinflammatory cytokines, such as Interleukin (IL) 15, IL 21, Tumor Necrosis Factor (TNF)

\footnotetext{
*Correspondence: f.forster@sciotec.at; oliver.spadiut@tuwien.ac.at

${ }^{2}$ Sciotec Diagnostics Technologies GmbH, Ziegelfeldstr. 3, 3430 Tulln, Austria

${ }^{1}$ Research Division Biochemical Engineering, Institute of Chemical,

Environmental and Bioscience Engineering, TU Wien, Vienna, Austria
}

alpha and Interferon (IFN) gamma (Fig. 1) [1, 3]. Thus, inflammations of the small bowel occur, ranging from intraepithelial lymphocytosis up to total villous atrophy combined with crypt hyperplasia [1, 3]. Hence, symptoms vary between asymptomatic, extra-intestinal manifestations, various abdominal complications, up to global malabsorption $[3,6]$. Long-term complications include malignancy, such as intestinal lymphomas and adenocarcinoma $[3,7,8]$.

To reduce symptoms and avoid long-term complications, a strict gluten free diet (GFD) is the only effective treatment of CD so far [3]. Due to the high prevalence, severe symptoms, long-term complications and limited treatment possibilities, it is self-explanatory that patients are in pressing need of additional and alternative therapies. Many novel drugs are in development and the results of the respective clinical trials are impatiently anticipated. As shown in Table 1 various novel therapies are under development, however none of these has reached clinical phase 3 investigations yet. Hence, unfortunately no novel therapy will be introduced to the

(c) The Author(s). 2018 Open Access This article is distributed under the terms of the Creative Commons Attribution 4.0 International License (http://creativecommons.org/licenses/by/4.0/), which permits unrestricted use, distribution, and 


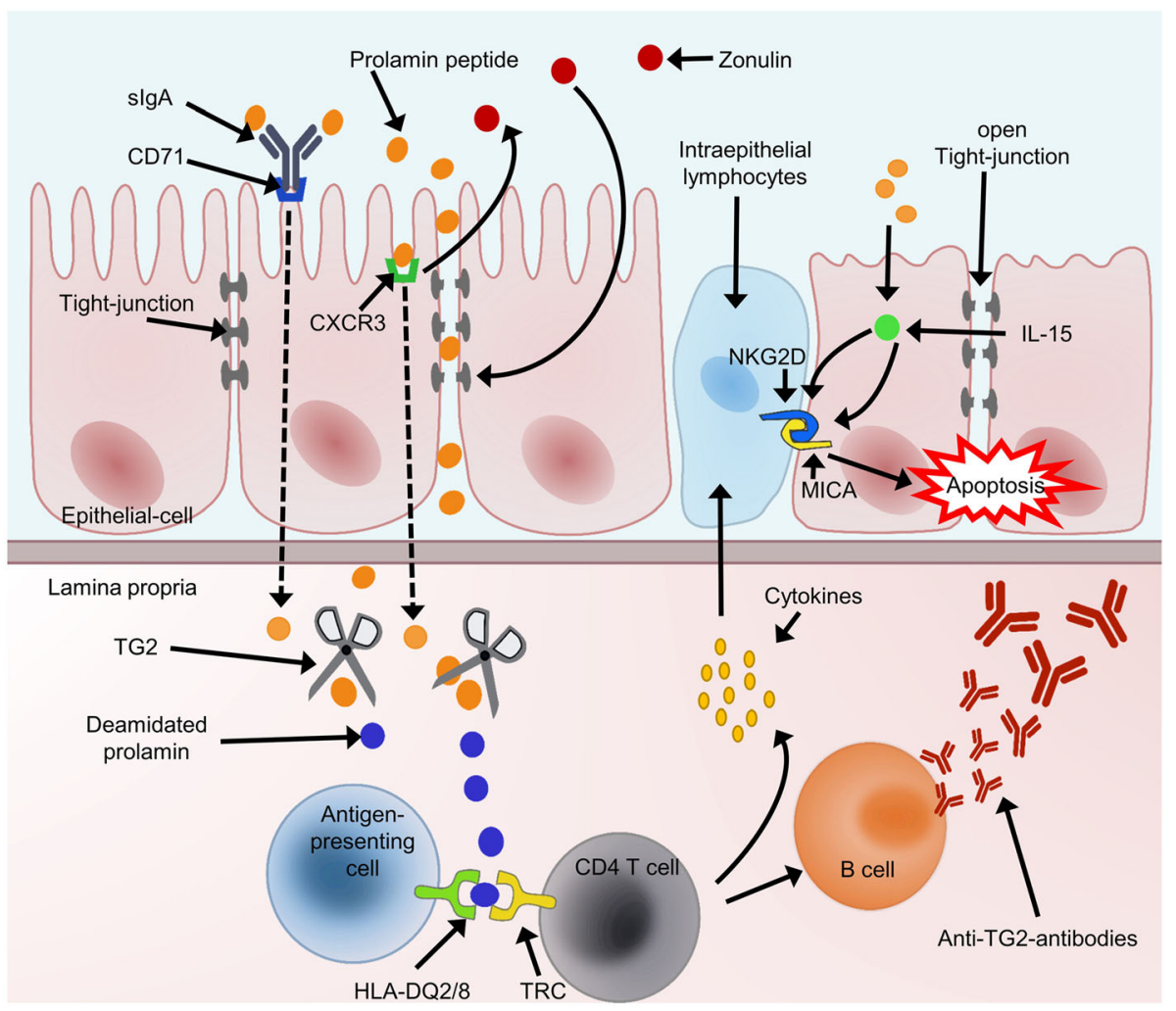

Fig. 1 Adapted simplified pathogenesis of celiac disease $[3,5,9]$. Prolamin overcomes the epithelial barrier via a transcellular transport as a soluble IgA-prolamin complex bound to an epithelial receptor (CD71). The interaction of prolamin with a chemokine receptor CXCR3 leads to the release of Zonulin, a protein that increases the permeability of the epithelium, due to opening of Tight-junctions and hence allows paracellular transport of prolamin. CD71, CXCR3 and Zonulin are upregulated in patients with celiac disease. Prolamin that reaches the lamina propria gets deamidated by transglutaminase 2 (TG2) and hence binds more strongly to human leukocyte antigens (HLA)-DQ2 and DQ8 molecules on antigen-presenting cells. These presented prolamins activate CD4 ${ }^{+} T$-cells, which then secrete proinflammatory cytokines. Furthermore, T-cells induce the expression of Interleukin (IL) 15 and autoantibodies against TG2 by innate immune cells. IL 15 has a very important role regarding the remodeling process of the intestinal surface. It leads to an upregulation of nonconventional HLA molecules, MICA on enterocytes, and activates NKG2D receptors on intraepithelial lymphocytes (IELs). The interaction of MICA and NKG2D promotes the downstream effect of IEL-mediated epithelial damage. Another source of IL 15 are epithelial and dendritic cells after contact with prolamin. To sum up, the contact of prolamin with the epithelial layer activates the innate and humoral immune system, which induces the destruction of the surface of the small intestine

market in the near future. Next to this lack of therapeutic options, a high social burden lies upon patients with CD, because a lifelong GFD is difficult to maintain. Even in "gluten-free" dietary products traces of prolamins are found, which have a severe impact on the well-being [10]. To support those patients we recently developed a novel single chain Fragment variable (scFv) against prolamins [11]. This scFv works as a "neutralizing agent", meaning that a complex between prolamin and the $\mathrm{scFv}$ is formed in the gut and no systemic interactions are expected, as the formed complex does not cross the epithelial barrier and is finally excreted. Thus, the scFv can be applied as a medical device. To obtain this novel $\mathrm{scFv}$, we immunized chicken with peptic tryptic digested gliadin (PT-gliadin). Those immunized chicken were used as source for RNA, carrying the sequence for the recombinant $\mathrm{scFv}$ [11]. Since no effector function of the antibody $(\mathrm{AB})$ is relevant for the neutralizing effect, but only the variable light and heavy chain are required, we generated a single chain Fragment variable (scFv). Since two antigen binding regions increase binding affinity, we joined two $\mathrm{scFv}$ with a peptide linker and constructed a tandem single chain Fragment variable (tscFv) [12, 13]. A block flow diagram of this process is presented in Additional file 1: Figure S1.

We selected Escherichia coli as production organism for recombinant tscFv, since E.coli is a common host for $\mathrm{scFv}$ production, due to its advantages of high cell density cultivations and high product titers [14-16]. Nevertheless, high translational rates, strong promotor systems and intrinsic product features often result in the formation of insoluble product aggregates, so-called Inclusion Bodies (IB) [17]. Downstream processing (DSP) of IBs is laborious and contains several steps 
Table 1 Potential therapies/supplementations for patients with celiac disease

\begin{tabular}{|c|c|c|c|c|c|c|}
\hline $\begin{array}{l}\text { Site of } \\
\text { action }\end{array}$ & Target & Principle of effect & Information/Drug & $\begin{array}{l}\text { Phase of } \\
\text { clinical } \\
\text { trial }\end{array}$ & $\begin{array}{l}\text { ClinicalTrials.gov } \\
\text { Identifier }\end{array}$ & $\overline{\text { Ref. }}$ \\
\hline \multirow[t]{6}{*}{$\begin{array}{l}\text { Intra- } \\
\text { luminal }\end{array}$} & Flours & $\begin{array}{l}\text { Pretreatment with lactobacilli, } \\
\text { transamidation of gliadin }\end{array}$ & $\begin{array}{l}\text { Microbial Transglutaminase and Lysine Ethyl } \\
\text { Ester (WHETMIT) }\end{array}$ & Phase 2 & NCT02472119 & [5] \\
\hline & Prolamin & $\begin{array}{l}\text { Polymetric binders, form high affinity } \\
\text { complexes with alpha-gliadin }\end{array}$ & $\begin{array}{l}\text { Poly-hydroxyethylmethacrylate-co-styrene } \\
\text { sulfonate } \\
\text { BL-7010 }\end{array}$ & Phase 2 & NCT01990885 & [5] \\
\hline & Prolamin & $\begin{array}{l}\text { Antibodies or Antibody-fragments with } \\
\text { high affinity to prolamin } \rightarrow \text { neutralizing } \\
\text { effect }\end{array}$ & $\begin{array}{l}\text { Tandem single chain Fragment variable } \\
\text { directed against prolamins of different grains } \\
\text { (Glutosin }{ }^{\mathrm{TM}} \text { ) }\end{array}$ & & & [10] \\
\hline & Prolamin & $\begin{array}{l}\text { Peptidase based, enzymes to degrade } \\
\text { prolamin }\end{array}$ & $\begin{array}{l}\text { - Cystein-Endopeptidas B2, Prolin- } \\
\text { Endopeptidase (ALVO03), } \\
\text { - Cocktail of microbial enzymes (STAN 1) } \\
\text { - Prolyl endopeptidase (AN-PEP) }\end{array}$ & $\begin{array}{l}\text { Phase } 1 \\
+2 \\
\text { Phase } 1 \\
+2 \\
\text { Phase } 1 \\
+2\end{array}$ & $\begin{array}{l}\text { NCT01255696 } \\
\text { NCT00962182 } \\
\text { NCT00810654 }\end{array}$ & $\begin{array}{l}{[5,} \\
11]\end{array}$ \\
\hline & Prolamin & $\begin{array}{l}\text { Bifidobacteria and lactobacillus species } \\
\text { that hydrolyse gliadin }\end{array}$ & $\begin{array}{l}\text { Bifidobacteria infantis and lactobacillus } \\
\text { species }\end{array}$ & & NCT01257620 & [5] \\
\hline & Prolamin & Desensitizing & $\begin{array}{l}\text { Necator americanus } \\
\text { - (NaCeD) } \\
\text { - (NainCeD-3) }\end{array}$ & $\begin{array}{l}\text { Phase } 1 \\
+2 \\
\text { Phase } 1\end{array}$ & $\begin{array}{l}\text { NCT01661933 } \\
\text { NCT02754609 }\end{array}$ & [5] \\
\hline \multirow[t]{3}{*}{$\begin{array}{l}\text { Epithelial } \\
\text { layer }\end{array}$} & $\begin{array}{l}\text { Zonulin } \\
\text { receptors }\end{array}$ & $\begin{array}{l}\text { Antagonizing Zonulin recetors, tight } \\
\text { junction modulation }\end{array}$ & $\begin{array}{l}\text { Larazotide acetate } \\
\text { (AT-1001) }\end{array}$ & Phase 2 & NCT01396213 & $\begin{array}{l}{[5,} \\
12]\end{array}$ \\
\hline & $\begin{array}{l}\text { Transcellular } \\
\text { gliadin } \\
\text { transport }\end{array}$ & $\begin{array}{l}\text { Inhibition of slgA-CD71 mediated } \\
\text { transport }\end{array}$ & & & & [5] \\
\hline & IL 15 & IL 15 action is blocked & $\begin{array}{l}\text { - Humanized Mik-Beta-1 Monoclonal Anti- } \\
\text { body Directed Toward IL-2//L-15R Beta } \\
\text { (CD122) (Hu-Mik- Beta-1) } \\
\text { - Human monoclonal antibody (AMG 714) }\end{array}$ & $\begin{array}{l}\text { Phase } 1 \\
\text { Phase } 2\end{array}$ & $\begin{array}{l}\text { NCT01893775 } \\
\text { NCT02637141 }\end{array}$ & [12] \\
\hline \multirow[t]{4}{*}{$\begin{array}{l}\text { Lamina } \\
\text { propria }\end{array}$} & $\begin{array}{l}\text { HLA- DQ2 or } \\
\text { DQ8 }\end{array}$ & Blocking HLA-DQ2 or DQ8 & & & & [12] \\
\hline & CCR3 & CCR3 blocking to repress T cell homing & CCX282-B & & NCT00540657 & [13] \\
\hline & TG2 & Inhibition of TG2 & & & & [12] \\
\hline & $\begin{array}{l}\text { Cathepsin-S } \\
\text { inhibitor }\end{array}$ & $\begin{array}{l}\text { Participate in the degradation of } \\
\text { antigenic proteins to peptides for } \\
\text { presentation on MHC class II }\end{array}$ & RG7625 & Phase 1 & NCT02679014 & [14] \\
\hline $\begin{array}{l}\text { Immune } \\
\text { system }\end{array}$ & $\begin{array}{l}\text { Immune } \\
\text { response }\end{array}$ & Vaccination & Nexvax2 & Phase 1 & NCT02528799 & [12] \\
\hline
\end{tabular}

including at least IB recovery, solubilization and refolding as key unit operations [17, 18]. A typical IB process is schematically shown in Fig. 2.

Besides the complexity of an IB process, the commonly low refolding yields describe further challenges [18-20]. On the other hand, IBs describe an efficient production strategy, not only because more than $30 \%$ of the cellular protein can be produced as IBs, but also because IBs contain a high level of the recombinant product, which is protected against proteolysis $[18,21]$.

In the current study, we recombinantly produced the novel tscFv in $E$. coli as IBs, processed the IBs following a standardized protocol and characterized the refolded product. Summarizing, we introduce a novel, recombinant
tscFv as an interesting biological agent to treat patients with CD.

\section{Methods \\ Chemicals}

All chemicals were purchased from Carl Roth $\mathrm{GmbH}$ (Vienna, Austria), if not stated otherwise.

\section{Strains and tscFv production Strain and construct}

The gene coding for the tandem single chain fragment variable $(\mathrm{tscFv})$ against PT-gliadin was cloned into the pET-28a(+) vector with an additional stop codon 


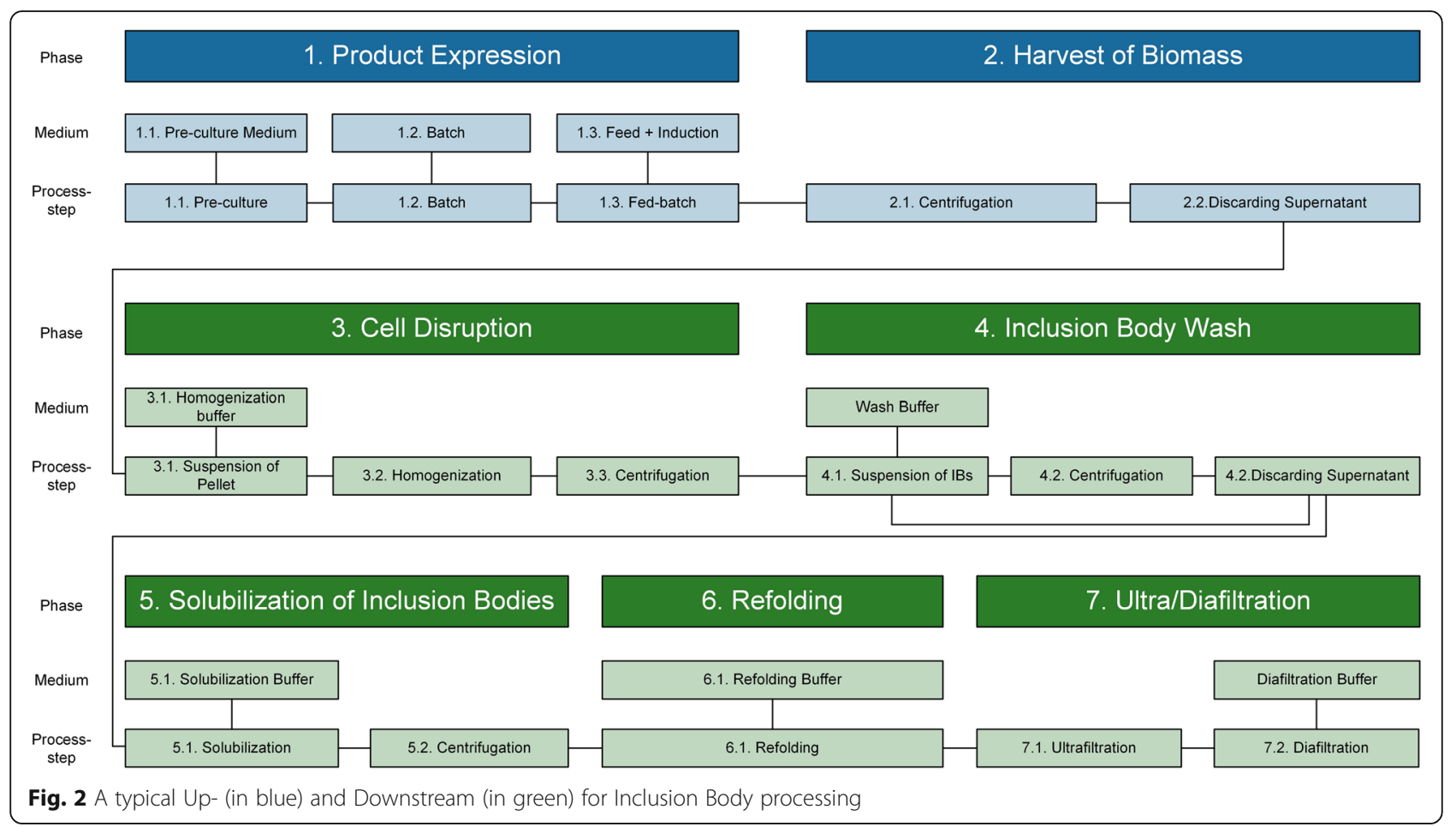

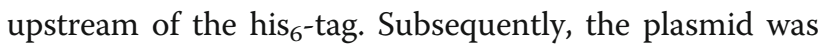
transformed into E.coli BL21(DE3) [11].

\section{Bioreactor cultivations}

Bioreactor cultivations were performed according to our previous study [22]. In short, $500 \mathrm{~mL}$ pre-culture (DeLisa medium [23]; $50 \mu \mathrm{g} / \mathrm{mL}$ Kanamycin) were used to inoculate $4500 \mathrm{~mL}$ sterile DeLisa medium in a stainless steel Sartorius Biostat Cplus bioreactor (Sartorius, Göttingen, Germany) with a working volume of $10 \mathrm{~L}$. After a batch (maximum specific growth rate $\left(\mu_{\max }\right)$ : $0.6 \mathrm{~h}^{-1}$; biomass end of batch: $8.1 \mathrm{~g}$ dry cell weight/L $(\mathrm{DCW} / \mathrm{L}))$ and a non-induced fed-batch $\left(\mu: 0.09 \mathrm{~h}^{-1}\right.$; biomass end of non-induced fed-batch: $47.6 \mathrm{~g} \mathrm{DCW} / \mathrm{L}$ ) for biomass $(\mathrm{BM})$ generation, cells were induced with $0.5 \mathrm{mM}$ Isopropyl $\beta$-D-1-thiogalactopyranoside (IPTG) at $30{ }^{\circ} \mathrm{C}$ for $10 \mathrm{~h}\left(\mu: 0.05 \mathrm{~h}^{-1}\right.$; biomass end of induced fed-batch: $56.2 \mathrm{~g} \mathrm{DCW} / \mathrm{L}$ ). Throughout the whole cultivation $\mathrm{pH}$ was kept at 7.2 and dissolved oxygen above $40 \%$. Biomass was harvested by centrifugation (179 g, $20 \mathrm{~min}, 4^{\circ} \mathrm{C}$ ) and stored at $-20^{\circ} \mathrm{C}$.

Sampling strategy Samples were taken at the beginning and the end of the batch, non-induced fed-batch and induced fed-batch. Specific product formation rates and final product yields were calculated for the induction phase of approximately $10 \mathrm{~h}$. Dry cell weight (DCW) was determined in triplicates, by centrifugation $\left(21,913 \mathrm{~g}, 4^{\circ} \mathrm{C}\right.$, $10 \mathrm{~min}$ ) of $1 \mathrm{~mL}$ cultivation broth, washing the obtained cell pellet with a $0.1 \% \mathrm{NaCl}$ solution and subsequent drying at $105{ }^{\circ} \mathrm{C}$ for $48 \mathrm{~h}$. Product, substrate and metabolites were quantified as described in our previous study [22].

\section{IB processing}

\section{IB recovery and purification}

Prior to cell disruption, frozen $\mathrm{BM}$ was thawed at $4{ }^{\circ} \mathrm{C}$ and suspended in $50 \mathrm{mM}$ Tris- $\mathrm{HCl}$ buffer, $\mathrm{pH}$ 8.0. BM concentration was adjusted to $10 \mathrm{~g}$ DCW/L. Cell disruption was performed by high-pressure homogenization using a PandaPLUS 2000 (GEA Mechanical Equipment, Parma, Italia). In total, 3 passages at 1500 bar were used to disrupt the cells. These conditions were chosen based on our previous study [24]. To limit heat generation, BM was kept on ice and a cooling unit was connected to the outlet of the homogenizer. Disrupted BM was centrifuged $\left(15,650 \mathrm{~g}, 4{ }^{\circ} \mathrm{C}, 20 \mathrm{~min}\right)$ and the supernatant was discarded. Then, IBs were washed with deionized water $(100 \mathrm{~g}$ wet weight/L $(\mathrm{WW} / \mathrm{L}))$. To ensure a homogeneous mixture, a T10 basic ULTRA-TURRAX ${ }^{\circ}$ (IKA, Staufen, Germany) was used $\left(2 \mathrm{~min}\right.$, stage $\left.5,4{ }^{\circ} \mathrm{C}\right)$. The suspension was centrifuged $\left(15,650 \mathrm{~g}, 4^{\circ} \mathrm{C}, 20 \mathrm{~min}\right)$ and the supernatant was discarded. This wash procedure was performed twice.

\section{IB solubilization and refolding}

$100 \mathrm{~g} \mathrm{WW/L}$ of washed IBs were resuspended in solubilization buffer (50 mM TRIS, 2 M Urea, 10\% v/v Glycerol, $\mathrm{pH}$ 12; [18]). The suspension was kept in an Infors 
HR Multitron shaker (Infors, Bottmingen, Switzerland) at room temperature (RT) at $100 \mathrm{rpm}$. After $60 \mathrm{~min}$, the solution was centrifuged $\left(15,650 \mathrm{~g}, 4{ }^{\circ} \mathrm{C}, 20 \mathrm{~min}\right)$ to remove insoluble cell components.

Refolding was performed by dilution. Solubilized IBs were added to the refolding buffer $(50 \mathrm{mM}$ Tris- $\mathrm{HCl}, 2 \mathrm{M}$ Urea, $10 \% \mathrm{v} / \mathrm{v}$ Glycerol, $\mathrm{pH} 8.5$, adjusted from $[25,26])$ to reach a protein concentration of $0.5 \mathrm{mg} / \mathrm{mL}$, corresponding to a 50 -fold dilution. The refolding preparation was kept at $14{ }^{\circ} \mathrm{C}$ and $100 \mathrm{rpm}$ in an Infors HR Multitron shaker (Infors, Bottmingen, Switzerland) for $48 \mathrm{~h}$. Yields were calculated based on HPLC measurements (see section "HPLC measurement").

\section{Ultra- and diafiltration}

Re-buffering (50 mM Tris-HCl, 5\% w/v Mannitol, $\mathrm{pH}$ 8.0) and concentration was performed with a Centramate $^{\mathrm{Tm}} 500 \mathrm{~S}$ Tangential Flow Filtration System (Pall, Austria; Vienna). Due to the calculated size of the tscFv of $52.9 \mathrm{kD}$, a Centramate Cassette with a $10 \mathrm{kD}$ cutoff and $0.1 \mathrm{~m}^{2}$ filtration area was used. Transmembrane pressure was kept below 0.7 bar. Prior to storage at $20{ }^{\circ} \mathrm{C}$, product aggregates were removed by filtration (0.2 $\mu \mathrm{m}$ pore-size).

\section{Biological assays Enzyme-linked immunosorbent assay (ELISA)}

To reassure the ability of the refolded product to neutralize antigens, ELISA analyses were performed. 96 well ELISA plates were either coated with $100 \mathrm{ng} /$ well PT-gliadin or coated with $1 \% w / v$ PEG 6000 as negative control. We described the coating protocol as well as the ELISA in detail in our previous study [11]. To reduce unspecific interactions, samples containing refolded tscFv or tscFv IBs were diluted with Tris-buffered saline (24.8 mM Tris, $136.9 \mathrm{mM} \mathrm{NaCl}$ and $2.7 \mathrm{mM} \mathrm{KCl}, \mathrm{pH} 8.0$ ) containing $0.05 \%$ Tween 20 (TBST). $100 \mu \mathrm{L}$ sample/well were incubated for an hour at $25{ }^{\circ} \mathrm{C}$ and $450 \mathrm{rpm}$. Every well was washed three times with $300 \mu \mathrm{L}$ TBST. Subsequently, $100 \mu \mathrm{L}$ of a 1:1000 dilution of Anti-Chicken IgG $(\mathrm{H}+\mathrm{L}), \mathrm{F}\left(\mathrm{ab}^{\prime}\right) 2$ fragment-Peroxidase antibody produced in rabbit (Sigma, Vienna, Austria) with TBST were added per well and incubated at $37^{\circ} \mathrm{C}$ and $450 \mathrm{rpm}$ for an hour (THERMOstar microplate incubator, BMG Labtech, Ortenberg, Germany). Each well was washed four times with $300 \mu \mathrm{L}$ TBST. A color reaction was mediated by the addition of $100 \mu \mathrm{L}$ premixed 3,3',5,5'-tetramethylbenzidine (TMB) substrate (Thermo Scientific, Vienna, Austria), which reacted with the peroxidase. After $15 \mathrm{~min}$, $50 \mu \mathrm{L}$ of $0.9 \mathrm{M} \mathrm{HCl}$ were added as stop reagent. Absorbance was measured at $450 \mathrm{~nm}$ in a Multiskan FC Microplate Photometer (Thermo Scientific, Vienna, Austria).

\section{Competitive ELISA}

To determine the binding affinity of the refolded product to a variety of prolamins of different flours, competitive ELISAs were performed. For this purpose, flours of different plants were digested with simulated gastric fluid $(0.1 \mathrm{mM}$ pepsin from porcine gastric mucosa, $55 \mathrm{mM} \mathrm{NaCl}, \mathrm{pH} 1.2)$ at $37{ }^{\circ} \mathrm{C}$ for $1 \mathrm{~h}$. The digest was centrifuged (2647 g, $5 \mathrm{~min}$ ) and the $\mathrm{pH}$ of the supernatant was adjusted to 8.5. Precipitating proteins were removed by centrifugation ( $2647 \mathrm{~g}, 5 \mathrm{~min}$ ) and the protein content of the supernatant was determined. Different concentrations $(1000,500,250,125,75,0.01$ and $0.0 \mu \mathrm{g}$ total protein $/ \mathrm{mL}$ ) of these digested flours (rye, barley, buckwheat, rice, maize, kamut, almond, soy, millet, spelt and wheat) were added to the ELISA plate with sample (refolded tscFv, tscFv IBs) and TBST, incubated and developed as described in 2.4.1. Due to this setup the applied digested flours and the immobilized PT-gliadin were competing over tscFv. Samples, which bound to predigested flours in the supernatant were washed away and thus the absorption signal was reduced. As positive control, anti-PT-gliadin-IgY extracted from egg yolk of PT-gliadin immunized hens was used. Also, a standard competitive ELISA, where PT-gliadin was competing against itself, was included.

Half maximal inhibitory concentration (IC50) IC50 values were calculated to exemplify competitive ELISA results. The values show the total protein concentration of predigested grains, which is necessary to reduce the detectable signal by half. Low IC50 values indicate a high affinity to the flours in the supernatant. IC50 values were calculated using SigmaPlot (Systat Software, San Jose, USA). A non-linear regression was performed and the equation for standard and four parameter logistic curves was used (Eq. 1).

$$
y=\min +\frac{(\max -\min )}{1+(x / \text { IC } 50)^{-H i l l s l o p e}}
$$

, where min is the bottom and max the top of the curve. Hillslope stands for the slope of the curve at its midpoint.

\section{Analytics}

\section{Protein measurement}

The protein content was determined using Bradford Coomassie Blue assay or Bicinchoninic acid assay (Sigma-Aldrich, Vienna, Austria). Bovine serum albumin (BSA) was used as a standard. To stay in the linear range of the detector (Genesys 20, Thermo Scientific, Waltham, MA, USA) samples were diluted with the respective buffer. 
Table 2 Strain physiological parameters of E. coli BL21(DE3) producing tscFv IBs

\begin{tabular}{|c|c|c|c|c|c|c|c|}
\hline & $\begin{array}{l}\text { cultivation } \\
\text { time }\end{array}$ & $\begin{array}{l}\text { specific glucose uptake } \\
\text { rate }\end{array}$ & $\begin{array}{l}\text { growth } \\
\text { rate }\end{array}$ & $\begin{array}{l}\text { Biomass } \\
\text { concentration }\end{array}$ & $\begin{array}{l}\mathrm{C}- \\
\text { balance }\end{array}$ & $\begin{array}{l}\text { specific product } \\
\text { titer }\end{array}$ & $\begin{array}{l}\text { volumetric product } \\
\text { titer }\end{array}$ \\
\hline & [h] & qs Gluc [g/g/h] & $\mu\left[h^{-1}\right]$ & & & & \\
\hline Batch & $0-6.7$ & 0.62 & 0.6 & 8.13 & 0.95 & & \\
\hline Fed-Batch & $6.7-22.4$ & 0.29 & 0.09 & 47.60 & 0.89 & & \\
\hline $\begin{array}{l}\text { Induced Fed- } \\
\text { Batch }\end{array}$ & $22.4-32.4$ & 0.20 & 0.05 & 56.15 & 1.01 & 40.90 & 2.30 \\
\hline
\end{tabular}

\section{HPLC measurement}

HPLC measurements were performed to gain information about 1) the purity of the solubilized IBs and 2) the purity and content of correctly refolded product. Therefore, particle-free samples of $5 \mu$ l were analyzed by an UltiMate $^{\text {TM }} 3000$ HPLC with a MAbPac ${ }^{\text {TM }}$ SEC-1 size exclusion column and an UltiMate ${ }^{\mathrm{TM}} 3000$ Multiple Wavelength Detector (Thermo Scientific, Vienna, Austria).
The mobile phase was either a $50 \mathrm{mM}$ BisTris buffer containing $4 \mathrm{M}$ Guanidinhydrochlorid $(\mathrm{GnHCl})$ and $100 \mathrm{mM} \mathrm{NaCl}$ (pH 6.8) for solubilized IBs, or $100 \mathrm{mM}$ $\mathrm{NaH}_{2} \mathrm{PO}_{4}$ buffer containing $300 \mathrm{mM} \mathrm{NaCl}(\mathrm{pH}$ 6.8) for the refolded product, respectively. The system was run with an isocratic flow of $100 \mu \mathrm{l} / \mathrm{min}$ at $25{ }^{\circ} \mathrm{C}$ column oven temperature. Every HPLC run included measurements of $29 \mathrm{kD}, 43 \mathrm{kD}$ and $75 \mathrm{kD}$ size standards (Gel
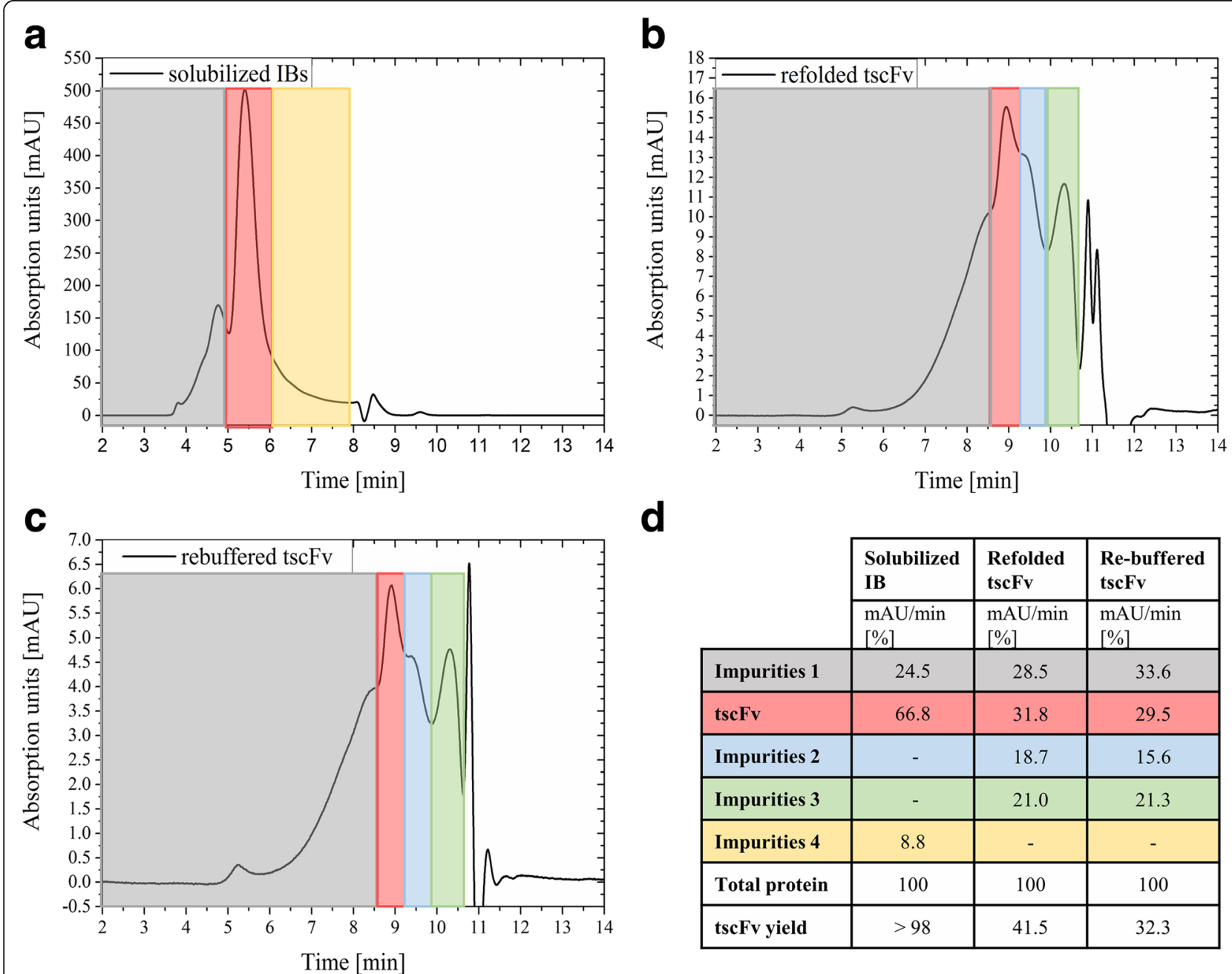

\begin{tabular}{|l|c|c|c|}
\cline { 2 - 4 } \multicolumn{1}{c|}{} & $\begin{array}{l}\text { Solubilized } \\
\text { IB }\end{array}$ & $\begin{array}{l}\text { Refolded } \\
\text { tscFv }\end{array}$ & $\begin{array}{l}\text { Re-buffered } \\
\text { tscFv }\end{array}$ \\
\cline { 2 - 4 } \multicolumn{1}{c|}{} & $\begin{array}{l}\mathrm{mAU} / \mathrm{min} \\
{[\%]}\end{array}$ & $\begin{array}{l}\mathrm{mAU} / \mathrm{min} \\
{[\%]}\end{array}$ & $\begin{array}{l}\mathrm{mAU} / \mathrm{min} \\
{[\%]}\end{array}$ \\
\hline Impurities 1 & 24.5 & 28.5 & 33.6 \\
\hline tscFv & 66.8 & 31.8 & 29.5 \\
\hline Impurities 2 & - & 18.7 & 15.6 \\
\hline Impurities 3 & - & 21.0 & 21.3 \\
\hline Impurities 4 & 8.8 & - & - \\
\hline Total protein & 100 & 100 & 100 \\
\hline tscFv yield & $>98$ & 41.5 & 32.3 \\
\hline
\end{tabular}

Fig. $3 \mathrm{HPLC}$ chromatograms at $280 \mathrm{~nm}$ and percentage of protein species. a, solubilized IBs; $\mathbf{b}$, refolded protein mixture; $\mathbf{c}$, refolded product after ultra- and diafiltration; $\mathbf{d}$, integral results of the different peaks in percent and yield calculations. Grey, Impurities 1 (lager in size than target protein); red, target protein; blue, Impurities 2; green, Impurities 3; yellow, Impurities 4. The other peaks in the chromatogram are buffer peaks 
Filtration LMW Calibration Kit, GE Healthcare, Vienna, Austria). Recorded chromatographic data at $280 \mathrm{~nm}$ were analyzed using OriginPro 9.1 (OriginLab Corporation, Northampton, United States). Since baseline separation was not achieved, borders (points of inflection) for peak integration were obtained by calculating the first derivative of the chromatographic data. Refolding yields were calculated using Eqs. 2-5. Areas of Standard proteins differed depending on the used mobile phase: using $\mathrm{GnHCl}$-containing buffer the area was smaller by a factor of $1.195 \pm 0.0027$. Hence, this factor was used as a correction factor during yield calculations.

$$
\begin{aligned}
\text { AUC total sol target }= & \frac{\text { AUC sol target }}{\text { injection volume }} \\
& * \text { volumesol }
\end{aligned}
$$

AUC corr totalsol $=$ AUC total sol target $* 1.195$

$$
\begin{aligned}
\text { AUC expected target }= & \frac{\text { Area corr total sol }}{\text { volume end }} \\
& * \text { injection volume }
\end{aligned}
$$

$$
\text { Yield }=\frac{\text { AUC measured target }}{\text { AUC expected target }} * 100
$$

\section{Product identification/qualification}

Product and host cell impurities in refolded product were analyzed by SDS-Page and subsequent mass spectrometry (MS) analysis. Therefore, bands of interest were excised from the gel, samples were digested with Trypsin (Promega, Mannheim, Germany) and proteins were S-alkylated with iodoacetamide. Peptides were extracted from the gel by a couple of washing steps. The digested samples were loaded on a BioBasic-18, $150 \times 0.32 \mathrm{~mm}$, $5 \mu \mathrm{m}$ column (Thermo Scientific, Vienna, Austria) using
$65 \mathrm{mM}$ Ammonium formate buffer (buffer A) as aqueous solvent. A gradient from 5\% B (B: 100\% Acetonitrile) to $32 \% \mathrm{~B}$ in $45 \mathrm{~min}$ was applied, followed by a $15 \mathrm{~min}$ gradient from $32 \%$ B to $75 \%$ B that facilitated elution of large peptides at a flow rate of $6 \mu \mathrm{L} / \mathrm{min}$. Detection was performed with MaXis 4G Q-TOF-MS (Bruker,Billerica MA, USA) equipped with the standard Electrospray ionization (ESI) source in positive ion, DDA mode (= switching to MSMS mode for eluting peaks). MS-scans were recorded (range: 150-2200 Da) and the six highest peaks were selected for fragmentation. Instrument calibration was performed using ESI calibration mixture (Agilent, Vienna, Austria). Analysis files were converted (using Data Analysis, Bruker) to MGF files, which are suitable for performing a MS/MS ion search with GPM (automated search engine). E.coli (strain K12) proteins and product sequence were inserted in the database for sequence identification.

\section{Results \\ Production of tscFv}

The fed-batch cultivation yielded $2.3 \mathrm{~g}$ IBs per L fermentation broth corresponding to a specific titer of $0.041 \mathrm{~g}$ $\mathrm{IB} / \mathrm{g} \mathrm{DCW}$ and a space-time-yield of $0.23 \mathrm{~g} \mathrm{IB} / \mathrm{L} / \mathrm{h}$ induction time. The strain-specific physiological parameters are shown in Table 2.

\section{IB processing}

Buffers and methods for IB processing were either developed in a previous study [24] or adapted from literature $[18,25,26]$. After cell disruption and IB wash, IBs were solubilized followed by refolding. Under the chosen conditions $(100 \mathrm{mg} \mathrm{WW} \mathrm{IB} / \mathrm{mL}$ solubilization buffer, solubilized for $1 \mathrm{~h}$ at room temperature) approximately $25 \mathrm{mg} /$ $\mathrm{mL}$ solubilized protein was found. This mixture of

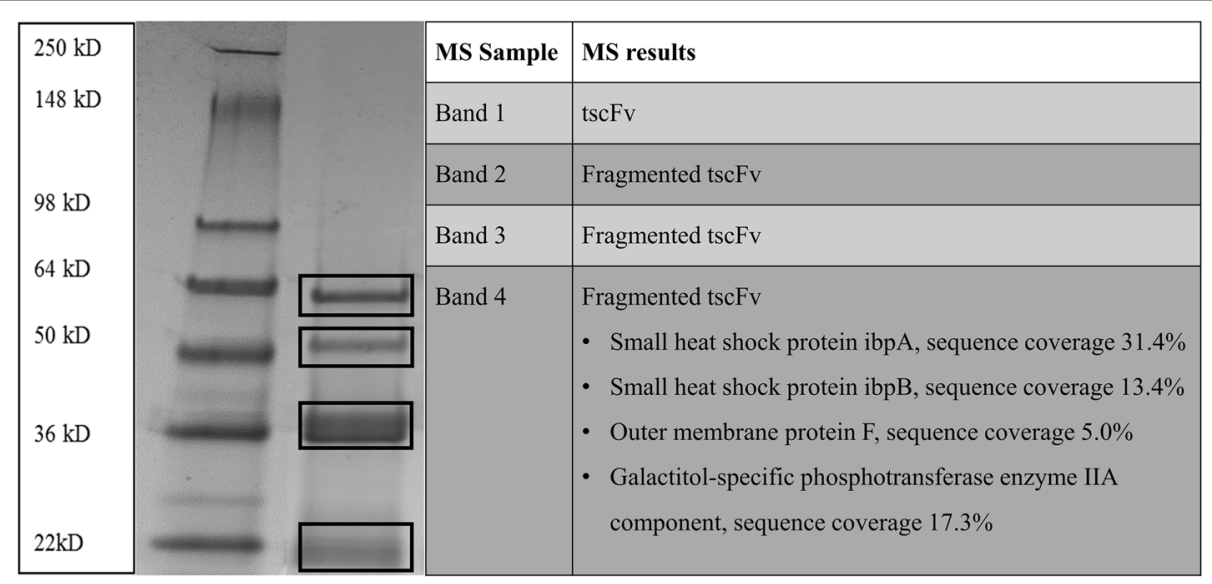

Fig. 4 SDS gel for MS analysis and the corresponding results. Left lane represents the protein ladder, right lane the applied refolded tscFv preparation; marked protein bands were excised and analyzed. MS results are presented in the Table. For all host cell impurities percentage of sequence coverage of the MS analysis are given 


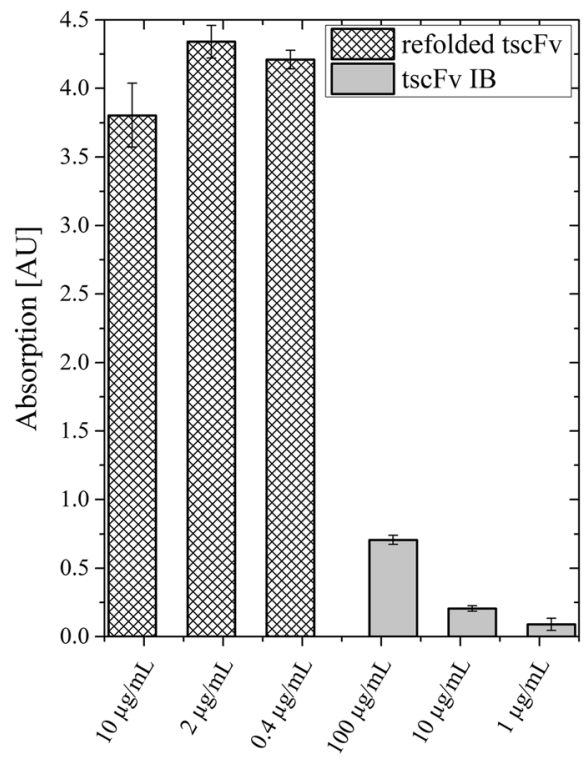

Sample concentration

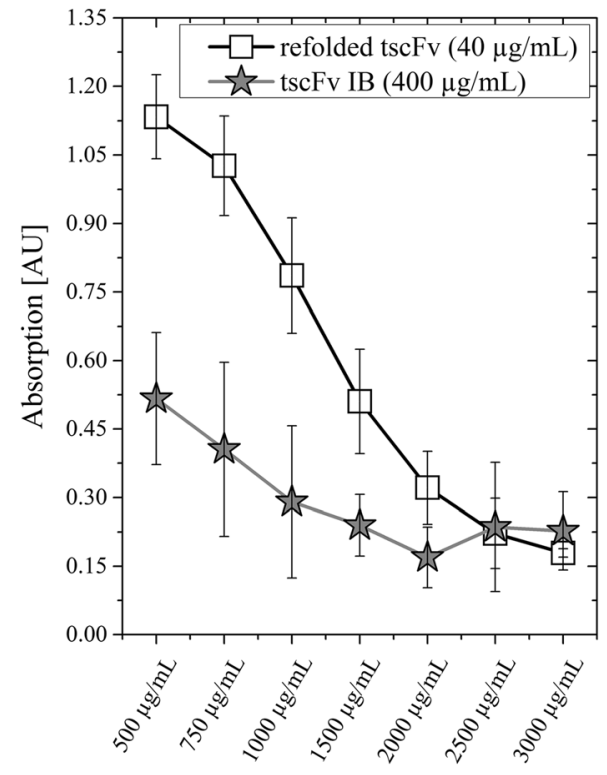

PT-gliadin

Fig. 5 Comparison of the binding capability of refolded tscFv and tscFv inclusion bodies (IBs). A, PT-gliadin ELISA where 10, 2 and $0.4 \mu \mathrm{g} / \mathrm{mL}$ refolded tscFv and 100, 10 or $1 \mu \mathrm{g} / \mathrm{mL}$ lyophilized and resuspended IBs were used; B, competitive ELISA, IBs ( $400 \mu \mathrm{g} / \mathrm{mL}$ ) or refolded tscFv $(40 \mu \mathrm{g} / \mathrm{mL}$ ) were applied with PT-gliadin and sample buffer. Signal reductions show that the samples are binding to increasing concentrations of PT-gliadin in the supernatant and not to the immobilized PT-gliadin on the plates
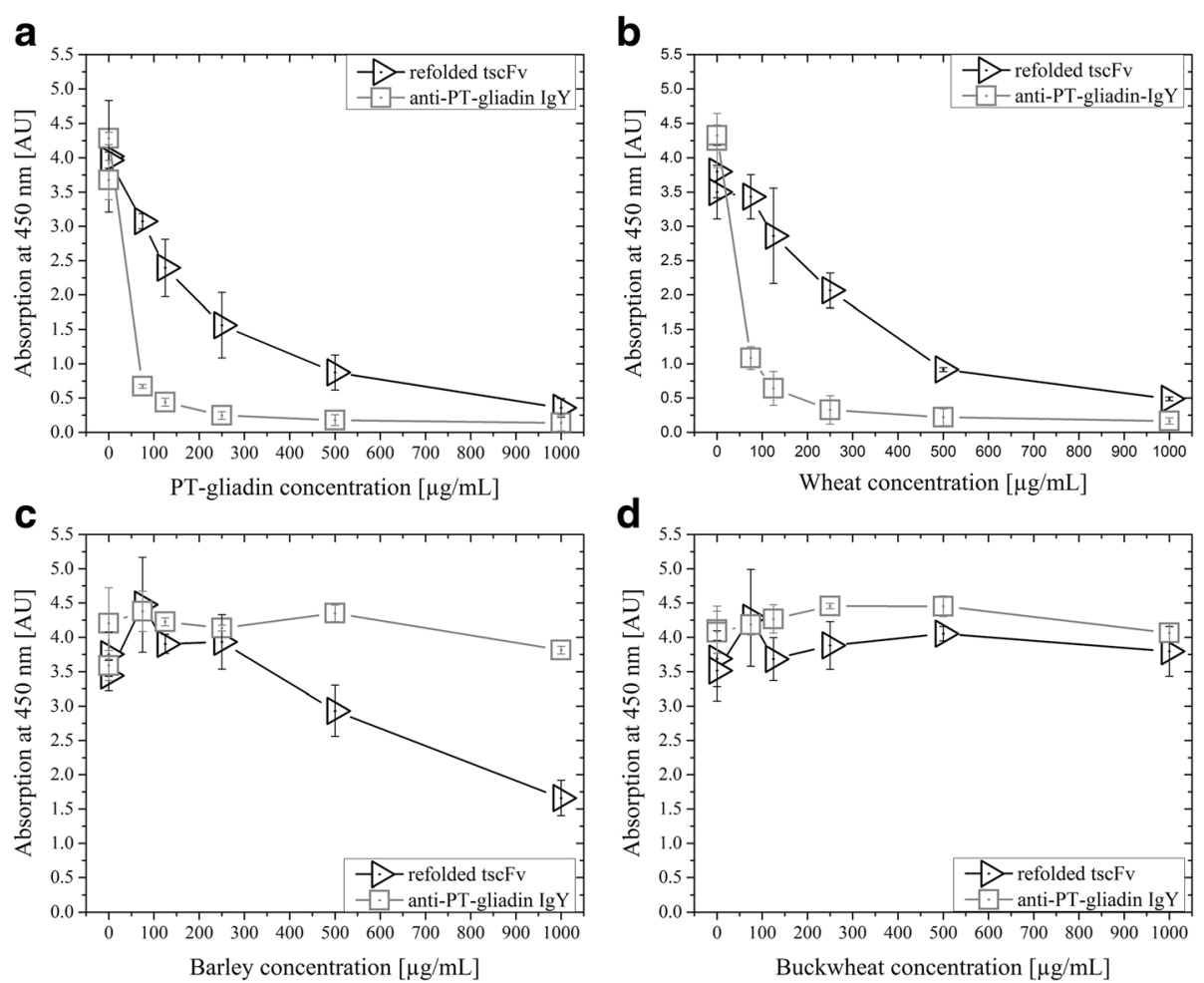

Fig. 6 Competitive ELISA of refolded tscFv and anti-PT-gliadin-lgY. $50 \mu \mathrm{g} / \mathrm{ml}$ sample (refolded tscFv or anti-PT-gliadin-lgY) were applied with different concentrations $(0,0.0075,75,125,250,500$ and $1000 \mu \mathrm{g} / \mathrm{mL})$ of $\mathbf{a}$, PT-gliadin; $\mathbf{b}$, wheat; c, barley; and d, buckwheat 

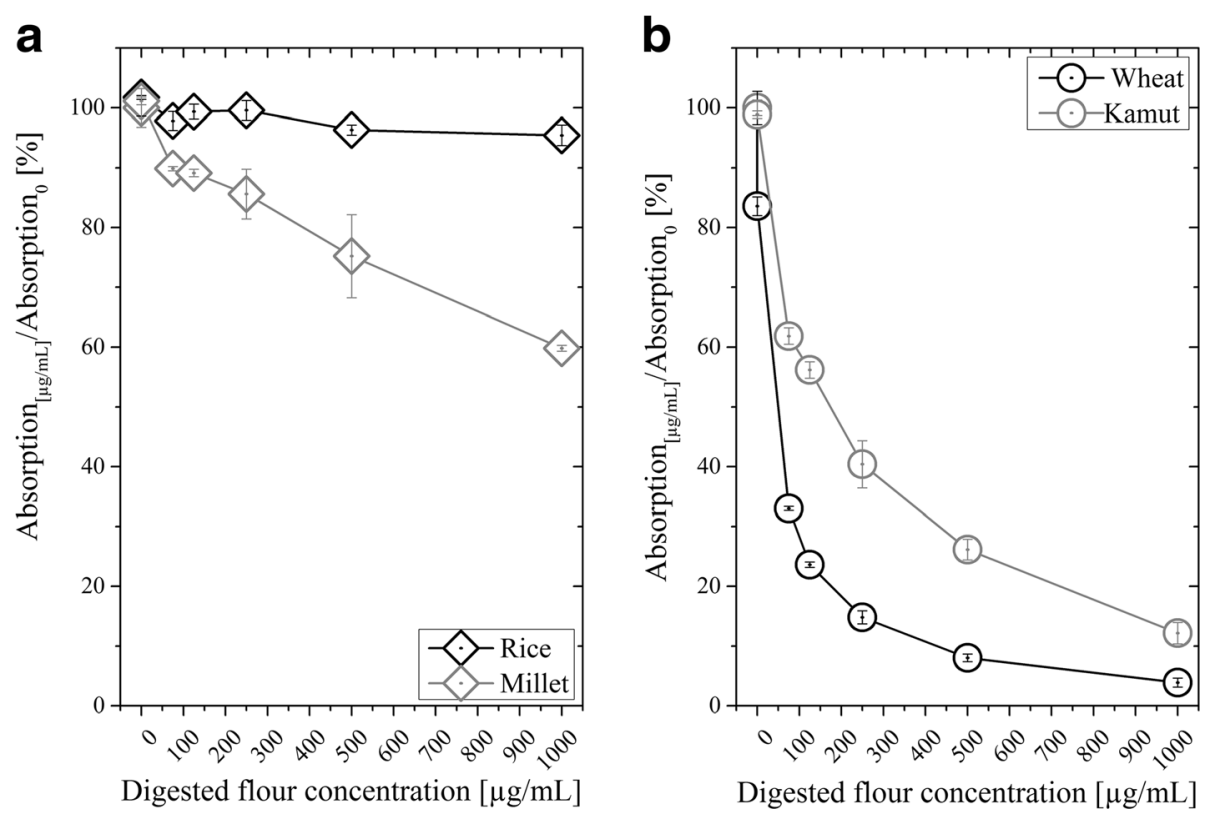

Fig. 7 Competitive ELISA of refolded tscFv and flours considered as safe (a) as well as flours known to trigger CD (b). The ability of flours from different grains to replace refolded tscFv from immobilized PT-gliadin was tested. The tscFv was applied in a concentration of $8 \mu \mathrm{g} / \mathrm{ml}$ with flours in predefined total protein concentrations $(0,0.0075,75,125,250,500$ and $1000 \mu \mathrm{g} / \mathrm{mL})$. The relative signal in $\%$ is shown. $100 \%$ signal corresponds to the signal obtained with tscFv without any flour

solubilized proteins mainly contained target protein, but also different host cell proteins and other impurities were found (Fig. 3a, d). HPLC measurements of the solubilized IBs revealed a purity of at least $66.8 \%$. This solubilized protein mixture was added to a refolding buffer for $48 \mathrm{~h}$. The refolding yield was calculated with $41.5 \%$ target protein (Eqs. 2-5; Fig. 3b, d), prior to concentration and re-buffering. After ultra- and diafiltration, another HPLC measurement was performed. At this step, an increase of impurities smaller than the target protein was found. The resulting chromatogram (Fig. 3c) showed $29.5 \%$ correctly folded target protein. Using Eqs. 2-5, the overall refolding yield was calculated with $32.3 \%$ (Fig. 3d).

\section{MS measurements}

To investigate the purity of the refolded and diafiltrated tscFv, MS analysis was performed. Therefore, the refolded tscFv was applied on an SDS gel and the different protein bands were excised and analyzed (Fig. 4). The SDS gel showed four dominant protein bands, which all contained the refolded product. Host cell proteins were only found to a small portion in the lowest band, indicating a high purity of the refolded product.

\section{Biological assays}

\section{Binding capability of tscFv IBs}

Literature has demonstrated that to some extent IBs can exhibit biological activity [27-30]. Therefore, we compared the binding capability of tscFv IBs and refolded tscFv using both a PT-gliadin and a competitive ELISA (Fig. 5). Figure 5a shows a PT-gliadin ELISA with refolded tscFv and tscFv IBs. Low concentrations of refolded tscFv led to no signal reduction of the ELISA, hence even the lowest applied concentration of $0.4 \mu \mathrm{g} /$

Table 3 Results of non-linear regression of the values received from competitive ELISAs

\begin{tabular}{|c|c|c|c|c|}
\hline & \multicolumn{4}{|c|}{ Sigmoidal, $4 \mathrm{PL}, \mathrm{X}$ is $\log$ (concentration) } \\
\hline & Applied grain & HillSlope & $\begin{array}{l}\text { IC50 } \\
{[\mu \mathrm{g} \text { grain/ } \mu \mathrm{g} \text { tscFv] }}\end{array}$ & R square \\
\hline \multirow[t]{6}{*}{ prolamin containing grains } & PT-gliadin & -1.26 & 5.79 & 0.998 \\
\hline & Wheat & -1.16 & 16.26 & 0.998 \\
\hline & Barley & -0.75 & 94.44 & 0.997 \\
\hline & Rye & -0.30 & 22.23 & 0.998 \\
\hline & Kamut & -0.63 & 32.60 & 0.998 \\
\hline & Spelt & -0.90 & 11.84 & 0.997 \\
\hline
\end{tabular}


$\mathrm{mL}$ saturated the assay. IBs, on the other hand, showed a low signal intensity, meaning that even a 10-times higher concentration of IBs $(100 \mu \mathrm{g} / \mathrm{mL})$ only led to a fifth of the signal intensity compared to refolded tscFv $(10 \mu \mathrm{g} / \mathrm{mL})$. Thus, a much higher IB concentration would be needed to achieve similar results compared to the refolded tscFv. This higher binding capacity of refolded tscFv was also found using a competitive ELISA (Fig. 5, b), where a 10 times higher concentration of IBs was necessary to get comparable results. Summarizing, although tscFv IBs show binding capabilities and do not have to be further processed to capture prolamins, higher concentrations of $\mathrm{tscFv}$ IBs are required to lead to the same effect as refolded tscFv.

\section{Comparison of refolded tscFv and anti-PT-gliadin-IgY}

In our previous study we showed that soluble $\mathrm{scFv}$ and standard anti-PT-gliadin-IgY displayed comparable binding capabilities [11]. In a similar fashion, we tested the refolded tscFv against the model protein $\mathrm{PT}$-gliadin and flour digests of wheat, barley and buckwheat and compared it to anti-PT-gliadin-IgY in a first comparative feasibility experiment (Fig. 6). Wheat is known for its high prolamin content (80\% of total proteins; [31]). We chose buckwheat as negative control, due to its reduced prolamin content [32].

As depicted in Fig. 6a and b a reduced concentration of PT-gliadin and digested wheat, respectively, was necessary to replace anti-PT-gliadin-IgY from immobilized PT-gliadin. However, anti-PT-gliadin-IgY showed no affinity to hordein, the prolamin of barley, whereas refolded tscFv did (Fig. 6c). For buckwheat neither anti-PT-gliadin-IgY nor refolded tscFv showed any neutralization capabilities (Fig. 6d). This comparative feasibility experiment demonstrated the desired biological activity of the refolded tscFv, which is why we analyzed this novel molecule also with flours of other grains.

\section{Binding capabilities of the refolded tscFv}

We analyzed the refolded tscFv in more detail for its missing affinity towards digested flours, that are certified as safe, namely maize, soy, buckwheat, almond, millet and rice (exemplarily shown in Fig. 7a) as well as its binding capabilities for prolamins known to trigger $\mathrm{CD}$, namely barley, rye, spelt, wheat and kamut (exemplarily shown in Fig. 7b).

As presented in Fig. 7a, the tscFv showed basically no activity with the flours of rice and millet. Slight responses observed for millet were due to the high concentration of digested flours, which led to a hindered interaction of immobilized PT-gliadin and tscFv. Also for the flours of other plants, which are basically prolamin-free, namely maize, soy, buckwheat and almond, we did not detect any biological activity.
However, the tscFv bound to flours from grains containing prolamins, as exemplarily shown for wheat and kamut in Fig. 7b. For better comparability, we calculated IC50 values for these flours, which indicate the concentration of PT-gliadin or digested flour, where the respective signal of the ELISA was reduced by half (Table 3). Low values indicate high affinity of tscFv and vice versa. As shown in Table 3, the lowest value of 5.79 was found for the pure antigen PT-gliadin, followed by spelt and wheat. Since we found the desired biological activity of the novel tscFv, we concluded that it represents a highly interesting treatment option for patients suffering from $\mathrm{CD}$, since it might be used as a medical device, which does not interact with the immune system.

\section{Discussion}

$\mathrm{CD}$ is a chronic disease involving the innate and adaptive immune system [1]. The immune system of genetically predisposed individuals responds to the dietary uptake of prolamin with inflammatory processes of the small intestine [3]. Hence, a strict livelong GFD has to be maintained and is currently the only option. However, a GFD is challenging because of hidden prolamins and costly dietary products, but also due to fear of prolamin exposure and hence possible social isolation [4, 33]. Thus, alternative and additional therapies are highly anticipated. In this study, we present a novel tscFv against various prolamins as a potential therapeutic support for patients with $\mathrm{CD}$. The tscFv, selected from a chicken gene library, was recombinantly produced in E.coli as IBs. It is known that such molecules are difficult to express in E. coli in a soluble form [34]. We achieved an IB titer of $2.3 \mathrm{~g}$ per L cultivation broth, corresponding to $4.1 \mathrm{mg} \mathrm{tscFv} / \mathrm{g} \mathrm{DCW} / \mathrm{h}$ induction time. This productivity is comparable to other biopharmaceuticals, such as Hirudin variant 1 , where a specific productivity of $6.0 \mathrm{mg} / \mathrm{g} / \mathrm{h}$ was achieved [35]. Even well-established processes, such as the production of insulin, only give a 3-times higher productivity of $14.2 \mathrm{mg} / \mathrm{g} / \mathrm{h}$ [36].

We demonstrated that the tscFv IB itself shows biological activity. However, compared to the refolded tscFv at least 10 -fold more tscFv IBs must be used to obtain a comparable biological effect. This circumstance clearly demands for the refolded product.

Renaturation of tscFv IBs, followed by ultra- and diafiltration, yielded $32 \%$ correctly folded target protein which represents a typical refolding yield in literature [37, 38]. During the IB process around $40 \%$ of product fragmented. However, we expect to further boost the refolding yield and reduce fragmentation by 1 ) buffer optimization; 2) determination of refolding kinetics and consequent adaptation of the process; 3) addition of stabilizers to reduce fragmentation (MS results indicated that the peptide 
linker was not stable during IB processing); and 4) changing the strategy from batch refolding by dilution to fed-batch refolding in the controlled environment of a refolding vessel.

When we investigated the binding capabilities of the tscFv with different flours, we found that lower concentrations of flours were capable to remove the standard polyclonal anti-PT-gliadin-IgY than refolded tscFv. This can be explained by the presence of product related impurities in the tscFv preparation (fragments) with lower binding affinity, which were confirmed by MS and HPLC analysis. Interestingly, anti-PT-gliadin-IgY showed no neutralizing effect with flour from barley. Only at high flour concentrations a reduction of the absorption signal was observed. However, this reduction is more likely explained by the high concentration of digested flower rather than the biological activity of anti-PT-gliadin-IgY. The tscFv not only shows a superior behavior towards the prolamins of barley compared to anti-PT-gliadin-IgY, but also compared to the scFv we examined in our previous study [11]. This higher binding affinity due to dimerization (and multimerization) is known in literature [12, 13]. Our binding study of tscFv with flours from different grains showed the desired outcome: tscFv bound to prolamin-containing flours, whereas no activity was detected with flours from grains, which are considered to be prolamin-free. We also performed an epitope mapping of the tscFv. We were able to identify the core epitope of the tscFv. The core epitope consists of an amino acid sequence containing almost exclusively prolines and glutamines - exactly those amino acids, which are problematic to digest in the gluten fraction and are contained in problematic prolamins. It also showed that the $\mathrm{tscFv}$ is binding to the 33-mer prolamin sequence, which is considered the most immune-toxic one, although with low affinity.

For a future application of this molecule we intend to deliver the $\mathrm{tscFv}$ to the intestine without getting destroyed by the hostile environment in the stomach. Packing the tscFv in micropellets coated with a gastric acid resistant film - traditionally by using shellac - is a suitable option for that purpose and has already proven to be extremely useful for two of our previous products (DAOsin ${ }^{\circ}$ and FRUCTOsin ${ }^{\circ}$ ). The galenic formulation in micropellets has two advantages. First, some micropellets pass the stomach very fast (like liquids) because they are not retarded by the pylorus. This ensures that tscFv is instantly provided together with prolamin containing food. Secondly, the micropellets staying in the stomach are delivered gradually with the chyme - constantly supplying tscFv. Furthermore, in a first feasibility experiment we tested the stability of the tscFv in the presence of two prominent enzymes in the stomach - namely trypsin and chymotrypsin - and still found more than
$50 \%$ of its initial biological activity after a $4 \mathrm{~h}$ incubation time (data not shown). In summary, we present a novel molecule, which can help patients suffering from CD. Our tscFv binds prolamins and can be used as a medical device. In vitro studies with Caco cell lines were promising and in vivo toxicity studies are currently ongoing.

\section{Conclusion}

Here we present a novel tscFv as an interesting medical device to support patients suffering from celiac disease. We show the production of this molecule as insoluble protein aggregates in E. coli, called inclusion bodies, and the subsequent processing to obtain correctly folded and active product. Finally, we demonstrate the biological activity of this tscFv and compare it to a standard anti-PT-gliadin-IgY. Overall, we believe that the tscFv will be an important therapeutic support, leading to reduced dietary complications triggered by the consumption of prolamins for patients suffering from celiac disease.

\section{Additional file}

Additional file 1: Figure S1. Block flow diagram of the workflow to generate the novel tandem single chain Fragment variable (tscFv) [11]. Red boxes show the immunization of the chicken, green boxes the identification and extraction of genes carrying the antigen binding site against peptic tryptic digested gliadin and blue boxes depict the simplified cloning strategy for the generation of the tscFv. (JPG $553 \mathrm{~kb}$ )

\section{Abbreviations}

AB: Antibody; BM: Biomass; BSA: Bovine serum albumin; CD: Celiac disease; DCW: Dry cell weight; DSP: Downstream processing; ELISA: Enzyme-linked immunosorbent assay; ESI: Electrospray ionization; GFD: Gluten free diet; HLA: Human leukocyte antigen; IB: Inclusion body; IC50: Half maximal inhibitory concentration; IEL: Intraepithelial lymphocyte; IFN: Interferon; IL: Interleukin; IPTG: Isopropyl $\beta$-D-1-thiogalactopyranoside; PT-gliadin: Peptic tryptic digested gliadin; scFv: Single chain Fragment variable; TBST: Tris buffered saline with 0.05\% Tween 20; TG2: Tissue transglutaminase2;

TMB: 3,3',5,5'-tetramethylbenzidine; TNF: Tumor necrosis factor; tscFv: Tandem single chain Fragment variable; WW: Wet weight

\section{Acknowledgements}

The authors are grateful to Prof. Friedrich Altmann and Clemens Grünwald Gruber (BOKU Wien, Austria) for MS analysis. The authors acknowledge the TU Wien University Library for financial support through its Open Access Funding Program.

\section{Availability of data and materials \\ The datasets analyzed during the current study are available from the corresponding author on reasonable request.}

\section{Authors' contributions}

FF and OS planed the study. IB production was performed by DW, IB processing and analytics were performed by BE. ELISA assays were performed by ES. OS supervised the study. The manuscript was written by BE and OS and critically reviewed by FF, ES and DW. All authors read and approved the final manuscript.

Ethics approval and consent to participate Not applicable. 


\section{Competing interests}

Sciotec Diagnostic Technologies $\mathrm{GmbH}$ holds a patent for the use of IgY and fragments thereof in CD therapy. FF and ES were employed by Sciotec Diagnostic Technologies $\mathrm{GmbH}$, when this study was conducted.

\section{Publisher's Note}

Springer Nature remains neutral with regard to jurisdictional claims in published maps and institutional affiliations.

Received: 13 October 2017 Accepted: 9 May 2018

Published online: 29 May 2018

\section{References}

1. Green PHR, Lebwohl B, Greywoode R. Celiac disease. J Allergy Clin Immunol. 2015;135(5):1099-106.

2. Bascunan KA, Vespa MC, Araya M. Celiac disease: understanding the glutenfree diet. Eur J Nutr. 2017;56(2):449-59.

3. Schuppan D, Junker Y, Barisani D. Celiac disease: from pathogenesis to novel therapies. Gastroenterology. 2009;137(6):1912-33.

4. Wungjiranirun $M$, Kelly CP, Leffler DA. Current status of celiac disease drug development. Am J Gastroenterol. 2016;111(6):779-86.

5. Kaukinen K, Lindfors K, Maki M. Advances in the treatment of coeliac disease: an immunopathogenic perspective. Nat Rev Gastroenterol Hepatol. 2014:11(1):36-44

6. Tack GJ, Verbeek WH, Schreurs MW, Mulder CJ. The spectrum of celiac disease: epidemiology, clinical aspects and treatment. Nat Rev Gastroenterol Hepatol. 2010;7(4):204-13.

7. Woodward J. Improving outcomes of refractory celiac disease - current and emerging treatment strategies. Clin Exp Gastroenterol. 2016;9:225-36.

8. van Gils T, Nijeboer P, van Wanrooij RL, Bouma G, Mulder CJ. Mechanisms and management of refractory coeliac disease. Nat Rev Gastroenterol Hepatol. 2015;12(10):572-9.

9. Kurppa K, Hietikko M, Sulic AM, Kaukinen K, Lindfors K. Current status of drugs in development for celiac disease. Expert Opin Investig Drugs. 2014; 23(8):1079-91.

10. Hundsberger $H$, Koppensteiner A, Hofmann E, Ripper D, Pfluger M, Stadlmann V, Klein CT, Kreiseder B, Katzlinger M, Eger A, et al. A screening approach for identifying Gliadin neutralizing antibodies on epithelial intestinal Caco-2 cells. SLAS Discov. 2017;1(8):1035-43.

11. Stadlmann V, Harant H, Korschineck I, Hermann M, Forster F, Missbichler A. Novel avian single-chain fragment variable (scFv) targets dietary gluten and related natural grain prolamins, toxic entities of celiac disease. BMC Biotechnol. 2015;15:109.

12. Holliger $P$, Hudson PJ. Engineered antibody fragments and the rise of single domains. Nat Biotechnol. 2005;23(9):1126-36.

13. Adams GP, Schier R, Marshall K, Wolf EJ, McCall AM, Marks JD, Weiner LM. Increased affinity leads to improved selective tumor delivery of single-chain Fv antibodies. Cancer Res. 1998;58(3):485-90.

14. Guglielmi L, Martineau P. Expression of single-chain Fv fragments in E. Coli cytoplasm. Methods Mol Biol. 2009:562:215-24.

15. Baeshen MN, Al-Hejin AM, Bora RS, Ahmed MM, Ramadan HA, Saini KS, Baeshen NA, Redwan EM. Production of biopharmaceuticals in E. Coli: current scenario and future perspectives. J Microbiol Biotechnol. 2015; 25(7):953-62.

16. Rosano GL, Ceccarelli EA. Recombinant protein expression in Escherichia coli: advances and challenges. Front Microbiol. 2014;5:172.

17. Singh A, Upadhyay V, Upadhyay AK, Singh SM, Panda AK. Protein recovery from inclusion bodies of Escherichia coli using mild solubilization process. Microb Cell Factories. 2015;14(1):41.

18. Singh SM, Panda AK. Solubilization and refolding of bacterial inclusion body proteins. J Biosci Bioeng. 2005;99(4):303-10.

19. Yamaguchi $H$, Miyazaki M. Refolding techniques for recovering biologically active recombinant proteins from inclusion bodies. Biomolecules. 2014:4(1):235-51.

20. Alibolandi $M$, Mirzahoseini $H$. Chemical assistance in refolding of bacterial inclusion bodies. Biochem Res Int. 2011; https://doi.org/10.1155/2011/ 631607

21. Villaverde A. Bacterial inclusion bodies: an emerging platform for drug delivery and cell therapy. Nanomedicine (Lond). 2012;7(9):1277-9.
22. Wurm DJ, Veiter L, Ulonska S, Eggenreich B, Herwig C, Spadiut O. The E. Coli pET expression system revisited - mechanistic correlation between glucose and lactose uptake. Appl Microbiol Biotechnol. 2016;100(20):8721-9.

23. DeLisa MP, Li J, Rao G, Weigand WA, Bentley WE. Monitoring GFP-operon fusion protein expression during high cell density cultivation of Escherichia coli using an on-line optical sensor. Biotechnol Bioeng. 1999;65(1):54-64.

24. Eggenreich B, Rajamanickam V, Wurm DJ, Fricke J, Herwig C, Spadiut O. A combination of HPLC and automated data analysis for monitoring the efficiency of high-pressure homogenization. Microb Cell Factories. 2017;16(1):134.

25. Song H-N, Jang J-H, Kim Y-W, Kim D-H, Park S-G, Lee MK, Paek S-H, Woo E-J. Refolded scFv antibody fragment against myoglobin shows rapid reaction kinetics. Int J Mol Sci. 2014;15(12):23658-71.

26. Bu D, Zhou Y, Tang J, Jing F, Zhang W. Expression and purification of a novel therapeutic single-chain variable fragment antibody against BNP from inclusion bodies of Escherichia coli. Protein Expr Purif. 2013;92(2):203-7.

27. Garcia-Fruitos E, Gonzalez-Montalban N, Morell M, Vera A, Ferraz RM, Aris A. Aggregation as bacterial inclusion bodies does not imply inactivation of enzymes and fluorescent proteins. Microb Cell Factories. 2005;4:27.

28. Villaverde A, Mar Carrió M. Protein aggregation in recombinant bacteria: biological role of inclusion bodies. Biotechnol Lett. 2003;25(17):1385-95.

29. de Groot NS, Ventura S. Protein activity in bacterial inclusion bodies correlates with predicted aggregation rates. J Biotechnol. 2006;125(1):110-3.

30. Peternel $\breve{S}$, Komel R. Isolation of biologically active nanomaterial (inclusion bodies) from bacterial cells. Microb Cell Factories. 2010:9:66.

31. El-Salhy MHJ, Hausken T. Is irritable bowel syndrome a stem cell disorder? World J Gastroenterol. 2014;20(2):384-400.

32. Comino I, de Lourdes Moreno M, Real A, Rodríguez-Herrera A, Barro F, Sousa $C$. The gluten-free diet: testing alternative cereals tolerated by celiac patients. Nutrients. 2013;5(10):4250-68.

33. Rashtak S, Murray JA. Review article: coeliac disease, new approaches to therapy. Aliment Pharmacol Ther. 2012;35(7):768-81.

34. Nelson AL. Antibody fragments: hope and hype. MAbs. 2010;2(1):77-83.

35. Matsui $T$, Sato $H$, Yamamuro H, Shinzato N, Matsuda H, Misawa S, Sato S High cell density cultivation of recombinant E. Coli for hirudin variant 1 production by temperature shift controlled by pUC18-based replicative origin. Appl Microbiol Biotechnol. 2008;80(5):779-83.

36. Baeshen NA, Baeshen MN, Sheikh A, Bora RS, Ahmed MMM, Ramadan HAl, Saini KS, Redwan EM. Cell factories for insulin production. Microb Cell Factories. 2014:13(1):141.

37. Sun $H$, Wu GM, Chen YY, Tian Y, Yue YH, Zhang GL. Expression, production, and renaturation of a functional single-chain variable antibody fragment (scFv) against human ICAM-1. Braz J Med Biol Res. 2014;47(7):540-7.

38. Gu Z, Weidenhaupt M, Ivanova N, Pavlov M, Xu B, Su Z-G, Janson J-C. Chromatographic methods for the isolation of, and refolding of proteins from, Escherichia coli inclusion bodies. Protein Expr Purif. 2002;25(1):174-9.

\section{Ready to submit your research? Choose BMC and benefit from}

- fast, convenient online submission

- thorough peer review by experienced researchers in your field

- rapid publication on acceptance

- support for research data, including large and complex data types

- gold Open Access which fosters wider collaboration and increased citations

- maximum visibility for your research: over $100 \mathrm{M}$ website views per year

At BMC, research is always in progress.

Learn more biomedcentral.com/submissions 